\title{
Identification of New Isolates of Phytophthora sojae and the Reactions of Korean Soybean Cultivars Following Hypocotyl Inoculation
}

\author{
In Jeong Kang', Sunjoo Kang ${ }^{2}$, Ik Hyun Jang², Yun Woo Jang ${ }^{3}$, Hyung Kwon Shim¹, Sunggi Heu', \\ and Sungwoo Lee $\mathbb{B}^{2 *}$ \\ ${ }^{1}$ Division of Crop Cultivation and Environment Research, Department of Central Area Crop Science, National Institute \\ of Crop Science, Suwon 16613, Korea \\ ${ }^{2}$ Department of Crop Science, Chungnam National University, Daejeon 34134, Korea \\ ${ }^{3}$ Department of Southern Area Crop Science, National Institute of Crop Science, Miryang 50424, Korea
}

(Received on September 19, 2019; Revised on November 2, 2019; Accepted on November 4, 2019)

Phytophthora root and stem rot (PRSR) caused by Phytophthora sojae is one of the most destructive diseases of soybean. PRSR recently became an issue as soybean cultivation in paddy fields increased in South Korea. The management of PRSR mainly involves $R$ gene-mediated resistance, however, little is known about the resistance in Korean cultivars. Major Korean soybean cultivars were investigated for the presence or absence of $R$-gene-mediated resistance to four $P$. sojae isolates, two of which were new isolates. Isolate-specific reactions were observed following $P$. sojae inoculation. Of 21 cultivars, 15-20 cultivars (71.4-95.2\%) showed susceptible reaction for each isolate. Ten cultivars were susceptible to all the isolates, and six cultivars were identified to have $\boldsymbol{R}$-gene-mediated resistance to one or two isolates. The results of this study would provide a framework for the discovery of resistant cultivars, development of new cultivars resistant to $P$. sojae, and investigation of pathogenic diversity of $P$. sojae population in South Korea.

Keywords : pathogenic diversity, Phytophthora root and

*Corresponding author.

Tel) +82-42-821-5727, FAX) +82-42-822-2631

E-mail)sungwoolee@cnu.ac.kr

ORCID

Sungwoo Lee

https://orcid.org/0000-0003-3564-2364

(c) This is an Open Access article distributed under the terms of the Creative Commons Attribution Non-Commercial License (http:// creativecommons.org/licenses/by-nc/4.0) which permits unrestricted noncommercial use, distribution, and reproduction in any medium, provided the original work is properly cited.

Articles can be freely viewed online at www.ppjonline.org. stem rot, race-specific resistance, $R$-gene, soybean

Handling Editor : Sohn, Kee Hoon

Phytophthora root and stem rot (PRSR) is a destructive soybean disease in major soybean-growing countries across the world. An average annual yield loss caused by PRSR was estimated as 1.1 million tons in the United States and Ontario, Canada, from 2007 to 2014, which ranked second to fifth among common soybean diseases (Allen et al., 2017; Koenning and Wrather, 2010; Wrather and Koenning 2009).

The causal agent Phytophthora sojae Kaufmann \& Gerdemann is a soil-borne oomycete pathogen, and soybean is its primary host (Kaufmann and Gerdemann, 1958). The occurrence of $P$. sojae was first reported in Indiana, the United States, in 1952, and it is widely distributed in the major soybean-growing regions including the U.S., Brazil, Argentina, China, Japan, and Australia (Akamatsu et al., 2019; Dorrance and Grünwald, 2009; Grau et al., 2004; Jee et al., 1998; Schmitthenner, 1985; Su and Shen, 1993). PRSR is a monocyclic disease, and $P$. sojae can overwinter in soil or plant debris and survive over 15 years (Schmitthenner, 1985). In poorly drained soil, it can germinate and produce zoospores that can infect roots of susceptible soybean genotypes. Disease symptoms include seedling damping-off at the early stage of growth, root and stem rot, yellowing, and wilting in susceptible plants during the later stage of growth (Schmitthenner, 1985).

The management of PRSR has mainly involved the genetic resistance of soybean conditioned by the single dominant resistance gene known as Rps (Resistance to Phytophthora sojae) (Dorrance, 2018). Rps-mediated resistance is 
qualitatively inherited and race-specific, and it generally provides complete defense to $P$. sojae, except Rps 2 which confers incomplete and root-specific resistance (Mideros et al., 2007). To date, over 30 resistance alleles have been identified or mapped on nine chromosomes of the soybean genome from different genetic sources in China, Japan, and South Korea (Anderson and Buzzell, 1992; Athow and Laviolette, 1982; Athow et al., 1980; Burnham et al., 2003; Buzzell and Anderson, 1992; Cheng et al., 2017; Demirbas et al., 2001; Diers et al., 1992; Gordon et al., 2006; Huang et al., 2016; Kilen et al., 1974; Li et al., 2017; Lin et al., 2013; Mueller et al., 1978; Niu et al., 2017; Sahoo et al., 2017; Sun et al., 2011; Sun et al., 2014; Weng et al., 2001; Zhang et al., 2013). Of the genes, a few, Rpsla, Rps1b, Rpslc, Rpslk, Rps3a, and Rps6, have been deployed into commercial soybean cultivars in the U.S. and Canada, and some have been fully characterized (Dorrance, 2018; Grau et al., 2004).

In South Korea, PRSR was first discovered in soybean fields located in Hongseong and Cheongyang, Chungnam in 1996 (Jee et al., 1998). Jee et al. (1998) identified an isolate of $P$. sojae (P-9664) in Chungnam and reported the levels of susceptibility of eight elite soybean cultivars to the $P$. sojae isolate. This isolate has not been considered as a severe problem for two decades. In recent years, paddy fields used for paddy rice cultivation are now being utilized for the cultivation of soybean and other upland crops. In such poorly drained fields, root rot diseases by soil-borne pathogens, e.g., $P$. sojae, have been reported to occur more frequently. There has been little study on the interaction between soybean and P. sojae isolates in South Korea in the recent decade, and thus, it is necessary to investigate the resistance of major soybean cultivars to $P$. sojae. The present study aimed (1) to report two new isolates of $P$. sojae, and (2) to evaluate major soybean cultivars against four isolates of $P$. sojae originating from South Korea.

A total of four isolates of $P$. sojae were used to inoculate plants in the present study (Table 1). Two isolates, P-9662 (KACC No. 40412) and P-98145 (KACC No. 40468), which were isolated in fields in Chungnam were obtained from the Korean Agricultural Culture Collection (KACC),
National Agrobiodiversity Center, Rural Development Administration, Suwon, Gyeonggi, South Korea. The other two were isolated from diseased plants found in soybean fields located in Suwon, Gyeonggi, and Miryang, Gyeongbuk, South Korea in 2016. The new P. sojae isolates were isolated in two geographic regions of South Korea distinct from previously reported locations, which indicates that the new isolates may be genetically different and possess virulence pathotypes that are different from those of isolates P-9662 and P-98145.

The isolation of a single zoospore was first conducted to obtain pure cultures of isolates. Two different media, $10 \%$ V8 agar and PBNIC media, were used for rapid cultivation and as Phytophthora semi-selective medium, respectively (Dorrance et al., 2008). PBNIC media contained Benlate ( $50 \%$ benomyl, $10 \mathrm{mg} / \mathrm{l}$ ), PCNB (pentachloronitrobenzene, $54 \mathrm{mg} / \mathrm{l}$ ), and Rovral (50\% iprodione, $40 \mathrm{mg} / \mathrm{l}$ ) for the control of nonpythiaceous fungi, and neomycin sulfate (100 $\mathrm{mg} / \mathrm{l})$ and chloramphenicol $(10 \mathrm{mg} / \mathrm{l})$ for bacterial control. All the PBNIC amendments, except Rovral, were added into $10 \% \mathrm{~V} 8$ agar, and the mixture was autoclaved for 30 min. Prior to pouring the agar into Petri dishes, Rovral was dissolved into the molten $10 \% \mathrm{~V} 8$ agar. Each isolate was grown on PBNIC media and on $10 \% \mathrm{~V} 8$ agar media at $26^{\circ} \mathrm{C}$ for 5-7 days under dark condition. For sporangia production, $P$. sojae-grown media were cut into $10-15$ pieces $\left(1 \mathrm{~cm}^{2}\right)$, and the agar blocks were transferred into a $50 \mathrm{ml}$ tube followed by the addition of sterilized water to make mycelial suspension of a 40-ml final volume. Mycelial suspension was homogenized, and $1 \mathrm{ml}$ of the suspension was transferred onto a 10\% V8 medium and spread out. After incubation at $26^{\circ} \mathrm{C}$ for 5 days under dark condition, a plug of the V8 medium, where a single sporangium was found, was cut and transferred onto a water agar medium. Next, $10-20 \mu \mathrm{l}$ of distilled water was added to the agar plug of the medium. The media were placed in $4^{\circ} \mathrm{C}$ for $30-50 \mathrm{~min}$, and the sporangia were observed with a microscope. For broken sporangia, water with a zoospore was pipetted into a $1.5 \mathrm{ml}$ tube and mixed with additional 50-100 $\mu$ of distilled water. A volume of $5 \mu \mathrm{l}$ of the zoospore suspension was pipetted on the surface of a water agar medium followed by incuba-

Table 1. List of four isolates of Phytophthora sojae used in the present study

\begin{tabular}{lcccc}
\hline Isolate ID & Year of isolation & Area of isolation & Name of infected plant & Reference \\
\hline P-9662 & 1996 & Chungnam & Unknown & KACC No. 40412 \\
P-98145 & 1996 & Chungnam & Unknown & KACC No. 40468 \\
Isolate 2457 & 2016 & Gyeongbuk & Wooram & First report \\
Isolate 3444-1 & 2016 & Gyeonggi & Unknown & First report \\
\hline
\end{tabular}

KACC, Korean Agricultural Culture Collection. 

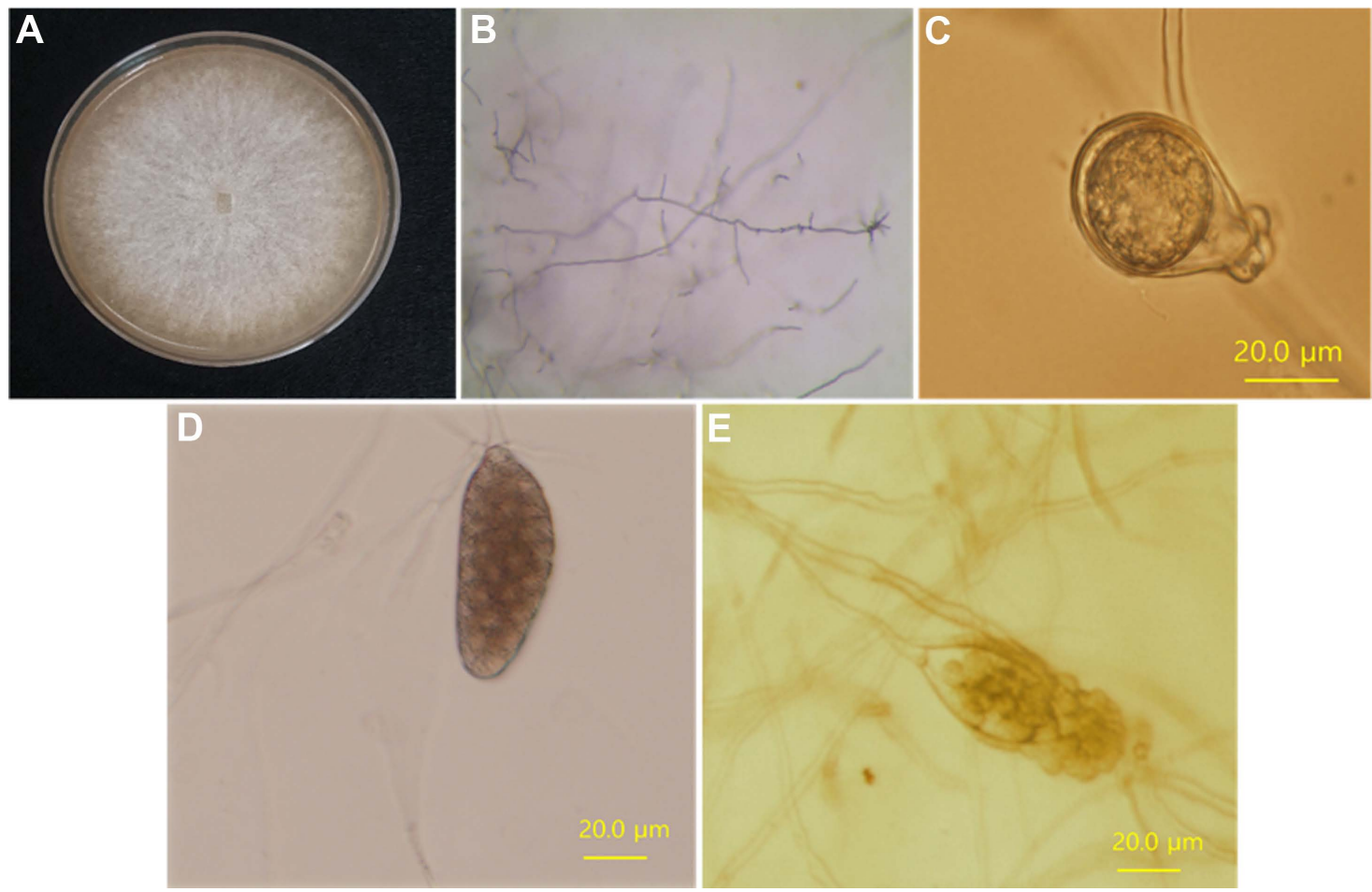

Fig. 1. Morphological characterization of a Phytophthora sojae isolate, P-9662 (KACC No. 40412), after single zoospore isolation. (A) Mycelium. (B) Slender, branched, coenocytic catenulate hyphae. (C) Oospore with amphygynous antheridium; oospore. (D) Sporangium. (E) Sporangium and release of zoospores. Scale bars $=20 \mu \mathrm{m}$.

tion at $26^{\circ} \mathrm{C}$ for $24 \mathrm{~h}$ under dark condition.

Following single spore isolation, the four isolates were morphologically characterized. P. sojae has a distinct, slow-growing pattern on PBNIC media (Dorrance et al., 2008). All the four $P$. sojae isolates grew slowly and mycelium appeared on PBNIC media after 2-3 days (data not shown). The morphology of mycelia, hyphae, oospore, sporangium, and zoospores was observed for each isolate 7 days after they were grown on $10 \% \mathrm{~V} 8$ media. The observed characteristic agreed with those expected in $P$. sojae for the four isolates. Fig. 1 presents the morphological characteristics of P-9662, as a representative of the four isolates. Mycelium was well-formed with white colony on $10 \% \mathrm{~V} 8$ media; it was branched to almost $90^{\circ}$, there were no septa in the mycelia, and the hyphal tips were curved (Fig. 1A and B). An oospore was well-formed with amphigynous antheridia on a 10\% V8 medium (Fig. 1C). Sporangia began to form 3 days after the spread-out of the mycelia suspension, and a sporangium was well-formed in 5 days (Fig. 1D). Zoospores released from a sporangium are shown in Fig. 1E.

The $P$. sojae isolates were also identified by polymerase chain reaction (PCR), in which two other Phytophthora species, $P$. infestans and $P$. capsici, were included as nega- tive controls. Isolates of $P$. infestans and $P$. capsici were obtained from the Highland Agriculture Research Institute, Pyeongchang-gun, Gangwon-do, South Korea, and the Gyeongsnagbuk-do Agricultural Research and Extension Service, Daegu, South Korea, respectively. Isolates were grown on $10 \% \mathrm{~V} 8$ media at $25^{\circ} \mathrm{C}$ in darkness for 5-7 days. Mycelia were scraped off from the cultures and macerated with $0.5 \mathrm{~mm}$ glass beads in $1.5 \mathrm{ml}$ tubes. Genomic DNA of each isolate was extracted using a NucleoSpin Plant $\Pi$ Kit (Macherey-Nagel, Düren, Germany) as per the manufacturer's protocol. The DNA concentration of each isolate was determined by a spectrophotometer (BioDrop, Cambridge, UK) and diluted in $50 \mathrm{ng} / \mu \mathrm{l}$. Pairs of PCR primers were suggested for molecular detection of $P$. sojae-specific internal transcribed spacer regions in previous studies (Bienapfl et al., 2011; Wang et al., 2006). P. sojae-specific primers, PSOJF1 (5'-GCCTGCTCTGTGTGGCTGT-3')/ PSOJR1 (5'-GGTTTAAAAAGTGGGCTCATGATC-3'), from the study of Bienapfl et al. (2011) were used to confirm the identification of $P$. sojae. PCR was performed using AccuPower PCR premix (Bioneer, Daejeon, Korea) as per the manufacturer's protocol and with a final volume of $20 \mu$, including $50 \mathrm{ng}$ of genomic DNA, 10 pmole primers, $1.0 \mathrm{U}$ of $\mathrm{Taq}$ polymerase (Bioneer), $250 \mu \mathrm{M} \mathrm{dNTP}, 1 \times$ 


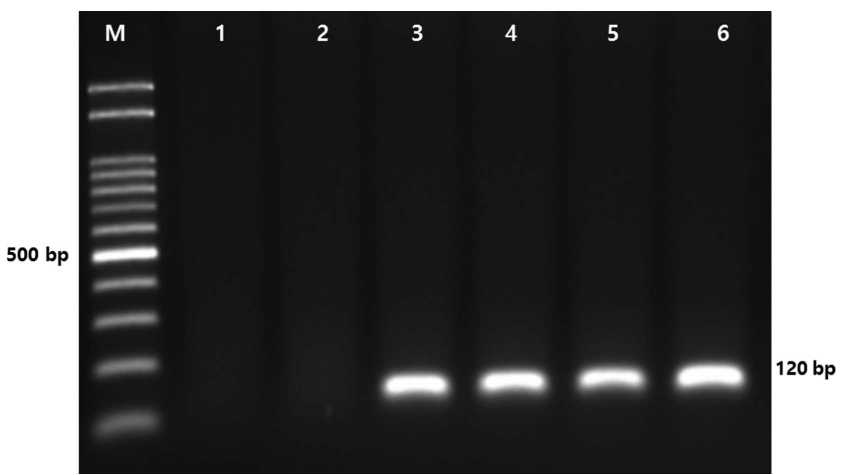

Fig. 2. Molecular detection of the four isolates of Phytophthora sojae by polymerase chain reaction with species-specific primers PSOJF1/PSOJR1 (Bienapfl et al., 2011). M, size marker (1002,000 bp); lane 1, negative control1 (Phytophthora infestans); lane 2, negative control2 (Phytophthora capsici); lane 3, P-9662 (KACC No. 40412) (P. sojae); lane 4, P-98145 (KACC No. 40468) (P. sojae); lane 5, isolate 2457 (P. sojae); lane 6, isolate 3444-1 (P. sojae). reaction buffer (10 mM Tris- $\mathrm{HCl}[\mathrm{pH} 9.0$ ], $30 \mathrm{mM} \mathrm{KCl})$. PCR was conducted as follows: an initial denaturation at $94^{\circ} \mathrm{C}$ for $5 \mathrm{~min}, 25$ cycles of $94^{\circ} \mathrm{C}$ for $30 \mathrm{~s}, 65^{\circ} \mathrm{C}$ for $30 \mathrm{~s}$, and $72^{\circ} \mathrm{C}$ for $30 \mathrm{~s}$, and a final extension at $72^{\circ} \mathrm{C}$ for $10 \mathrm{~min}$. The PCR products were resolved on a $1.5 \%$ Tris-BorateEDTA agarose gel and stained with Dyne LoadingStar (Dyne Bio, Seongnam, Korea). A clear PCR band of approximately 120-130 bp was amplified using the primers PSOJF1/R1 for the four isolates of $P$. sojae, whereas no amplicon was observed for the two other species (Fig. 2). The sizes of the PCR amplicons of the four P. sojae isolates were highly consistent with those in previously published studies (Bienapfl et al., 2011; Stewart, 2011). The negative controls demonstrated the specificity of the PCR amplification for $P$. sojae. The result provides molecular evidence for the identification of $P$. sojae, in addition to the morphological characteristics described above.

A total of 21 soybean genotypes were evaluated to investigate the presence or absence of $R$-gene-mediated

Table 2. Reactions of soybean genotypes following hypocotyl inoculation of the four isolates of Phytophthora sojae

\begin{tabular}{|c|c|c|c|c|}
\hline \multirow{2}{*}{ Name of genotype } & \multicolumn{4}{|c|}{ Reactions } \\
\hline & P-9662 & P-98145 & Isolate 2457 & Isolate 3444-1 \\
\hline Williams (Susceptible check) & $\mathrm{S}$ & S & $\mathrm{S}$ & $\mathrm{S}$ \\
\hline Nampung & $\mathrm{S}$ & $\mathrm{S}$ & $\mathrm{S}$ & $\mathrm{S}$ \\
\hline Dawon & $\mathrm{S}$ & S & $\mathrm{S}$ & $\mathrm{S}$ \\
\hline Daewon & $\mathrm{S}$ & $\mathrm{S}$ & $\mathrm{R}$ & $\mathrm{S}$ \\
\hline Daepung & $\mathrm{S}$ & S & $\mathrm{S}$ & $\mathrm{S}$ \\
\hline Daepung2 & $\mathrm{S}$ & $\mathrm{S}$ & $\mathrm{R}$ & $\mathrm{S}$ \\
\hline Myungjunamul & $\mathrm{S}$ & S & $\mathrm{S}$ & S \\
\hline Seonyu & $\mathrm{S}$ & $\mathrm{S}$ & $\mathrm{S}$ & I \\
\hline Seonpung & $\mathrm{S}$ & $\mathrm{S}$ & $\mathrm{S}$ & I \\
\hline Sinpaldal2 & $\mathrm{S}$ & S & $\mathrm{S}$ & $\mathrm{S}$ \\
\hline Sinhwa & $\mathrm{S}$ & $\mathrm{S}$ & $\mathrm{S}$ & $\mathrm{S}$ \\
\hline Yeonpung & $\mathrm{S}$ & S & $\mathrm{S}$ & $\mathrm{S}$ \\
\hline Wooram & $\mathrm{S}$ & $\mathrm{S}$ & $\mathrm{S}$ & $\mathrm{S}$ \\
\hline Jinpung & $\mathrm{S}$ & $\mathrm{S}$ & $\mathrm{S}$ & $\mathrm{S}$ \\
\hline Cheonsang & $\mathrm{S}$ & $\mathrm{S}$ & $\mathrm{I}$ & I \\
\hline Cheonga & $\mathrm{S}$ & $\mathrm{S}$ & $\mathrm{S}$ & I \\
\hline Cheongja & $\mathrm{S}$ & $\mathrm{R}$ & $\mathrm{S}$ & $\mathrm{R}$ \\
\hline Taekwang & I & $\mathrm{S}$ & $\mathrm{S}$ & I \\
\hline Pungsannamul & S & $\mathrm{R}$ & $\mathrm{R}$ & S \\
\hline Pungwon & $\mathrm{S}$ & $\mathrm{S}$ & $\mathrm{R}$ & $\mathrm{S}$ \\
\hline Hwangkeum & S & $\mathrm{S}$ & $\mathrm{R}$ & $\mathrm{S}$ \\
\hline No. of resistant genotypes (\%) & $0(0)$ & $2(9.5)$ & $5(23.8)$ & $1(4.8)$ \\
\hline No. of susceptible genotypes (\%) & $20(95.2)$ & $19(90.5)$ & $15(71.4)$ & $15(71.4)$ \\
\hline No. of intermediate genotypes (\%) & $1(4.8)$ & $0(0)$ & $1(4.8)$ & $5(23.8)$ \\
\hline
\end{tabular}

$\mathrm{R}$, resistant reaction; $\mathrm{S}$, susceptible reaction; I, intermediate reaction. 
resistance to $P$. sojae using the four isolates, including 20 soybean cultivars most widely grown in South Korea and a U.S. cultivar, 'Williams,' as a susceptible control that has none of the known Rps genes (Dorrance et al., 2004; Wagner and Bernard, 1991). Inoculum preparation and hypocotyl inoculation were conducted as described by Dorrance et al. (2008). Isolates of $P$. sojae were grown on diluted V8 media (15 g of agar per liter) for 7 days. P. sojae-grown media were transferred into a $50 \mathrm{ml}$ syringe and macerated by passing through the syringe twice to obtain mycelial slurry of $P$. sojae immediately prior to inoculation. Approximately, 10 seedlings of each genotype were grown in a 13-cm-diameter round plastic pot for 7 days. A $1 \mathrm{~cm}$ slit was made on the center of hypocotyl of the 7-day-old seedlings using a scalpel, and approximately $80 \mu \mathrm{l}$ of mycelial slurry was injected into the slit on the hypocotyl using 10 $\mathrm{ml}$ syringes with an 18-guage needle attached. Inoculated seedlings were placed in a dew chamber (Dasol Scientific Co., Ltd., Hwaseong, Korea) overnight and then incubated in a growth chamber at $25^{\circ} \mathrm{C}$. Per genotype, the numbers of dead and alive seedlings were counted 5-7 days after inoculation. The reactions of genotypes were determined as the following criteria: resistant if less than $20 \%$ dead seedlings, susceptible if over $80 \%$ dead seedlings, or intermediate if $20-80 \%$ dead seedlings (Dorrance et al., 2008). The experiment was repeated three times.

The reactions of the soybean cultivars following the inoculation of the four $P$. sojae isolates are summarized in Table 2. The presence of expanded lesion and dead seedlings indicated susceptible interaction, and healed wound and healthy seedlings were observed in resistant interaction (Fig. 3A and B). The phenotypic reaction was isolate-specific in the respective soybean cultivars against each isolate, which means that a resistant cultivar to one isolate can be susceptible to another isolate. This type of resistance is generally explained by Flor's gene-for-gene theory which describes that resistance can be conditioned when an Avirulence ( $A v r$ ) gene of a pathogen and an $R$-gene of a resistant plant interact after inoculation (Flor, 1971). Intermediate reaction was observed in a few interactions along with resistance and susceptibility. Overall, the levels of virulence of the four isolates for the major cultivars were medium to high according to the percentages of susceptible reaction; 15-20 genotypes (71.4-95.2\%) showed susceptible reaction for each isolate. Six cultivars, including Daepung2, Cheongja, and Pungsannamul, exhibited resistant reaction for one or two isolates, whereas ten cultivars, including Daepung, Wooram, and Myungjunamul, were susceptible to all the four isolates used in the present study. This result indicates that many of the soybean cultivars widely grown in South Korea are susceptible to multiple $P$. sojae isolates and are potentially under threat in fields where $P$. sojae exists. Interestingly, the two KACC isolates could infect $>90 \%$ of the tested genotypes, indicating higher levels of pathogenic virulence compared to the other new isolates. No cultivar was resistant to P-9662, only two were resistant to P-98145, and five cultivars exhibited resistance to isolate 2457.

The four $P$. sojae isolates showed various virulence patterns based on the reactions of the 21 cultivars after inoculation. These results imply that there is genetic diversity in $P$. sojae population, and $P$. sojae isolates with differing pathotypes may be distributed across the geographic regions in South Korea. Both isolates P-9662 and P-98145 were identified in Chungnam and showed similar results of reactions following inoculation, whereas the other two isolated from Gyeonggi and Gyeongbuk exhibited reaction patterns distinguished from those of the Chungnam isolates. This
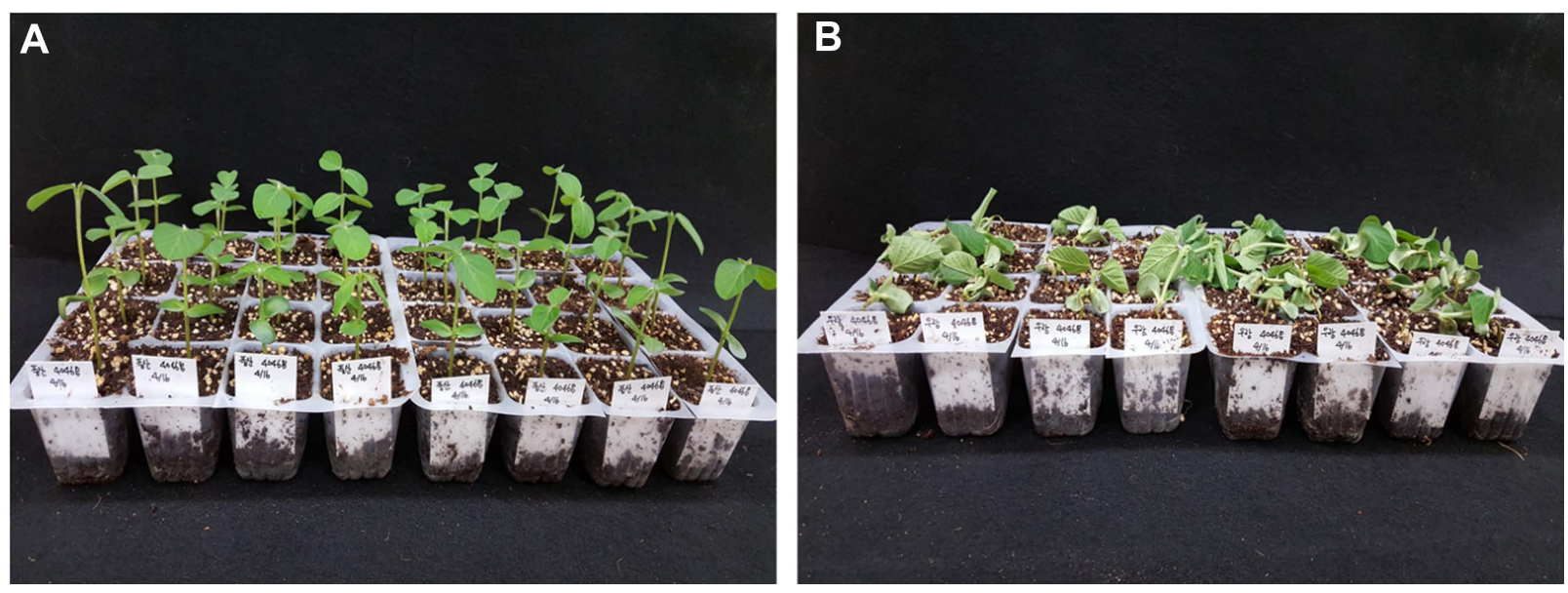

Fig. 3. Resistant and susceptible reaction following inoculation of P-98145 into soybean cultivars Pungsannamul (A) and Wooram (B). 
result implies that there is genetic diversity or variability in virulence pathotypes across the geographical regions or among $P$. sojae isolates originating from South Korea. Genetic diversity and changes in $P$. sojae population have been reported in multiple countries (Abney et al., 1997; Dorrance, 2018; Dorrance and Grünwald, 2009; Sugimoto et al., 2012; Zhang et al., 2010). Further investigation of $P$. sojae population using large numbers of $P$. sojae isolates would provide a great framework for soybean breeding to achieve race-specific resistance to $P$. sojae.

In summary, the present study reported two new $P$. sojae isolates recently identified in two geographical regions in South Korea and confirmed their identification based on morphological features and molecular evidence by PCR. Major Korean soybean cultivars were tested for resistance against four $P$. sojae isolates using the hypocotyl inoculation technique. We found that six cultivars showed racespecific and immune-mediated resistance to only an isolate or two following hypocotyl inoculation. No genotypes were resistant to all the four isolates, and ten cultivars had susceptible reaction following the inoculation of all the four isolates. Although the number of $P$. sojae isolates was small, the results indicate that $P$. sojae population varies with the geographic regions of South Korea. In addition, the two new isolates have different virulence pathotypes, which are also different from those of the existing isolates based on the tested soybean genotypes. Many of the major soybean cultivars are potentially threatened by $P$. sojae infection. Therefore, the discovery of $P$. sojae-resistant germplasm, as well as the identification and introduction of $R$-gene-mediated resistance, is required for the improvement of current soybean cultivars in South Korea.

\section{Acknowledgments}

This study was co-funded by research grants from the Cooperative Research Program for Agriculture Science \& Technology Development (Project title: Reduction of soilborne pathogens of soybean cultivated in paddy field using the change of microbiome, Project No. PJ012553) and the Next-Generation BioGreen 21 Program (Project title: Identification of resistance to Phytophthora sojae in the Korean soybean core collection and NAM population, Project No. PJ013337), Rural Development Administration, South Korea.

\section{References}

Abney, T. S., Melgar, J. C., Richards, T. L., Scott, D. H., Grogan, J. and Young, J. 1997. New races of Phytophthora sojae with Rps1-d virulence. Plant Dis. 81:653-655.
Akamatsu, H., Kato, M., Ochi, S., Mimuro, G., Matsuoka, J.-I. and Takahashi, M. 2019. Variation in the resistance of Japanese soybean cultivars to Phytophthora root and stem rot during the early plant growth stages and the effects of a fungicide seed treatment. Plant Pathol. J. 35:219-233.

Allen, T. W., Bradley, C. A., Sisson, A. J., Byamukama, E., Chilvers, M. I., Coker, C. M., Collins, A. A., Damicone, J. P., Dorrance, A. E., Dufault, N. S., Esker, P. D., Faske, T. R., Giesler, L. J., Grybauskas, A. P., Hershman, D. E., Hollier, C. A., Isakeit, T., Jardine, D. J., Kelly, H. M., Kemerait, R. C., Kleczewski, N. M., Koenning, S. R., Kurle, J. E., Malvick, D. K., Markell, S. G., Mehl, H. L., Mueller, D. S., Mueller, J. D., Mulrooney, R. P., Nelson, B. D., Newman, M. A., Osborne, L., Overstreet, C., Padgett, G. B., Phipps, P. M., Price, P. P., Sikora, E. J., Smith, D. L., Spurlock, T. N., Tande, C. A., Tenuta, A. U., Wise, K. A. and Wrather, J. A. 2017. Soybean yield loss estimates due to diseases in the United States and Ontario, Canada, from 2010 to 2014. Plant Health Prog. 18:19-27.

Anderson, T. R. and Buzzell, R. I. 1992. Inheritance and linkage of the Rps 7 gene for resistance to Phytophthora rot of soybean. Plant Dis. 76:958-959.

Athow, K. L. and Laviolette, F. A. 1982. Rps 6, a major gene for resistance to Phytophthora megasperma f. sp. glycinea in soybean. Phytopathology 72:1564-1567.

Athow, K. L., Laviolette, F. A., Mueller, E. H. and Wilcox, J. R. 1980. A new major gene for resistance to Phytophthoramegasperma var sojae in soybean. Phytopathology 70:977980.

Bienapfl, J. C., Malvick, D. K. and Percich, J. A. 2011. Specific molecular detection of Phytophthora sojae using conventional and real-time PCR. Fungal Biol. 115:733-740.

Burnham, K. D., Dorrance, A. E., Francis, D. M., Fioritto, R. J. and Martin, S. K. S. 2003. Rps8, a new locus in soybean for resistance to Phytophthora sojae. Crop Sci. 43:101-105.

Buzzell, R. I. and Anderson, T. R. 1992. Inheritance and race reaction of a new soybean Rps1 allele. Plant Dis. 76:600-601.

Cheng, Y., Ma, Q., Ren, H., Xia, Q., Song, E., Tan, Z., Li, S., Zhang, G. and Nian, H. 2017. Fine mapping of a Phytophthora-resistance gene RpsWY in soybean (Glycine max L.) by high-throughput genome-wide sequencing. Theor. Appl. Genet. 130:1041-1051.

Demirbas, A., Rector, B. G., Lohnes, D. G., Fioritto, R. J., Graef, G. L., Cregan, P. B., Shoemaker, R. C. and Specht, J. E. 2001. Simple sequence repeat markers linked to the soybean Rps genes for Phytophthora resistance. Crop Sci. 41:1220-1227.

Diers, B. W., Mansur, L., Imsande, J. and Shoemaker, R. C. 1992. Mapping Phytophthora resistance loci in soybean with restriction fragment length polymorphism markers. Crop Sci. 32:377-383.

Dorrance, A. and Grünwald, N. J. 2009. Phytophthora sojae: diversity among and within populations. In: Oomycete genetics and genomics: diversity, interactions, and research tools, eds. by K. Lamour and S. Kamoun, pp. 197-212. John Wiley \& Sons, Inc., Hoboken, NJ, USA.

Dorrance, A. E. 2018. Management of Phytophthora sojae of 
soybean: a review and future perspectives. Can. J. Plant Pathol. 40:210-219.

Dorrance, A. E., Berry, S. A., Anderson, T. R. and Meharg, C. 2008. Isolation, storage, pathotype characterization, and evaluation of resistance for Phytophthora sojae in soybean. Plant Health Prog. Online publication. DOI: 10.1094/php-20080118-01-dg.

Dorrance, A. E., Jia, H. and Abney, T. S. 2004. Evaluation of soybean differentials for their interaction with Phytophthora sojae. Plant Health Prog. Online publication. DOI: 10.1094/ PHP-2004-0309-01-RS.

Flor, H. H. 1971. Current status of the gene-for-gene concept. Annu. Rev. Phytopathol. 9:275-296.

Gordon, S. G., Martin, S. K. S. and Dorrance, A. E. 2006. Rps 8 maps to a resistance gene rich region on soybean molecular linkage group F. Crop Sci. 46:168-173.

Grau, C. R., Dorrance, A. E., Bond, J. and Russin, J. S. 2004. Fungal diseases. In: Soybeans: improvement, production, and uses, eds. by H. R. Boerma and J. E. Specht, pp. 679763. American Society of Agronomy. Crop Science Society of America. Soil Science Society of America, Madison, WI, USA.

Huang, J., Guo, N., Li, Y., Sun, J., Hu, G., Zhang, H., Li, Y., Zhang, X., Zhao, J., Xing H. and Qiu, L. 2016. Phenotypic evaluation and genetic dissection of resistance to Phytophthora sojae in the Chinese soybean mini core collection. BMC Genet. 17:85.

Jee, H. J., Kim, W. G. and Cho, W. D. 1998. Occurrence of Phytophthora root rot on soybean (Glycine max) and identification of the causal fungus. Crop Prot. 40:16-22.

Kaufmann, M. J. and Gerdemann, J. W. 1958. Root and stem rot of soybean caused by Phytophthora sojae n. sp. Phytopathology 48:201-208.

Kilen, T. C., Hartwig, E. E. and Keeling, B. L. 1974. Inheritance of a second major gene for resistance to Phytophthora rot in soybeans. Crop Sci. 14:260-262.

Koenning, S. R. and Wrather, J. A. 2010. Suppression of soybean yield potential in the continental United States by plant diseases from 2006 to 2009. Plant Health Prog. Online publication. DOI: 10.1094/PHP-2010-1122-01-RS.

Li, Y., Sun, S., Zhong, C., Wang, X., Wu, X. and Zhu, Z. 2017. Genetic mapping and development of co-segregating markers of $R p s Q$, which provides resistance to Phytophthora sojae in soybean. Theor. Appl. Genet. 130:1223-1233.

Lin, F., Zhao, M., Ping, J., Johnson, A., Zhang, B., Abney, T. S., Hughes, T. J. and Ma, J. 2013. Molecular mapping of two genes conferring resistance to Phytophthora sojae in a soybean landrace PI 567139B. Theor. Appl. Genet. 126:21772185.

Mideros, S., Nita, M. and Dorrance, A. E. 2007. Characterization of components of partial resistance, Rps2, and root resistance to Phytophthora sojae in soybean. Phytopathology 97:655662.

Mueller, E. H., Athow, K. L. and Laviolette, F. A. 1978. Inheritance of resistance to four physiologic races of Phytophthora megasperma var. sojae. Phytopathology 68:1318-1322.

Niu, J., Guo, N., Sun, J., Li, L., Cao, Y., Li, S., Huang, J., Zhao, J., Zhao, T. and Xing, H. 2017. Fine mapping of a resistance gene RpsHN that controls Phytophthora sojae using recombinant inbred lines and secondary populations. Front. Plant Sci. $8: 538$.

Sahoo, D. K., Abeysekara, N. S., Cianzio, S. R., Robertson, A. E. and Bhattacharyya, M. K. 2017. A novel Phytophthora sojae resistance Rps 12 gene mapped to a genomic region that contains several Rps genes. PLoS ONE 12:e0169950.

Schmitthenner, A. F. 1985. Problems and progress in control of Phytophthora root rot of soybean. Plant Dis. 69:362-368.

Stewart, S. M. 2011. Characterization and management of genetic diversity in Phytophthora sojae populations. Ph.D. thesis. Iowa State University, Ames, IA, USA.

$\mathrm{Su}$, Y. C. and Shen, C. Y. 1993. The discovery and biological characteristics studies of Phytophthora megasperma f. sp. glycinea on soybean in China. Acta Phytopathol. Sin. 23:341347 (in Chinese).

Sugimoto, T., Kato, M., Yoshida, S., Matsumoto, I., Kobayashi, T., Kaga, A., Hajika, M., Yamamoto, R., Watanabe, K., Aino, M., Matoh, T., Walker, D. R., Biggs, A. R. and Ishimoto, M. 2012. Pathogenic diversity of Phytophthora sojae and breeding strategies to develop Phytophthora-resistant soybeans. Breed. Sci. 61:511-522.

Sun, J., Li, L., Zhao, J., Huang, J., Yan, Q., Xing, H. and Guo, N. 2014. Genetic analysis and fine mapping of RpsJS, a novel resistance gene to Phytophthora sojae in soybean [Glycine $\max ($ L.) Merr.]. Theor. Appl. Genet. 127:913-919.

Sun, S., Wu, X. L., Zhao, J. M., Wang, Y. C., Tang, Q. H., Yu, D. Y., Gai, J. Y. and Xing, H. 2011. Characterization and mapping of RpsYu25, a novel resistance gene to Phytophthora sojae. Plant Breed. 130:139-143.

Wagner, R. E. and Bernard, R. L. 1991. Response of Williams isolines to eight races of Phytophthora megasperma $\mathrm{f}$. $\mathrm{sp}$. glycinea. Soybean Genet. Newsl. 18:236-239.

Wang, Y., Zhang, W., Wang, Y. and Zheng, X. 2006. Rapid and sensitive detection of Phytophthora sojae in soil and infected soybeans by species-specific polymerase chain reaction assays. Phytopathology 96:1315-1321.

Weng, C., Yu, K., Anderson, T. R. and Poysa, V. 2001. Mapping genes conferring resistance to Phytophthora root rot of soybean, Rpsla and Rps7. J. Hered. 92:442-446.

Wrather, A. and Koenning, S. 2009. Effects of diseases on soybean yields in the United States 1996 to 2007. Plant Health Prog. Online publication. DOI: 10.1094/PHP-2009-0401-01RS.

Zhang, J., Xia, C., Wang, X., Duan, C., Sun, S., Wu, X. and Zhu, Z. 2013. Genetic characterization and fine mapping of the novel Phytophthora resistance gene in a Chinese soybean cultivar. Theor. Appl. Genet. 126:1555-1561.

Zhang, S., Xu, P., Wu, J., Xue, A. G., Zhang, J., Li, W., Chen, C., Chen, W. and Lv, H. 2010. Races of Phytophthora sojae and their virulences on soybean cultivars in Heilongjiang, China. Plant Dis. 94:87-91. 